\title{
UJ KETAHANAN LARVA UDANG GALAH DARI BEBERAPA SUMBER POPULASI TERHADAP BAKTERI Vibrio harveyi
}

\author{
Ikhsan Khasani, Dinamella Wahjuningrum, dan Yan Evan \\ Loka Riset Pemuliaan dan Teknologi Budidaya Perikanan Air Tawar \\ Jl. Raya Sukamandi No. 2, Subang \\ E-mail:ikhsankhasani@yahoo.com
}

(Naskah diterima: 8 Maret 2010; Disetujui publikasi: 12 Agustus 2010)

\begin{abstract}
ABSTRAK
Salah satu penyakit yang sering menyerang udang di pembenihan adalah vibriosis, yang disebabkan oleh bakteri Vibrio harveyi. Penelitian bertujuan untuk mengetahui tingkat ketahanan beberapa strain larva udang galah, yaitu asal Sungai Ogan, Sumatera Selatan; Sungai Asahan, Sumatera Utara; Sungai Barito, Kalimantan Selatan; Sungai Ciasem, Jawa Barat; dan strain GIMacro terhadap infeksi bakteri Vibrio harveyi, sebagai dasar perakitan varietas unggul udang galah. Penelitian dilakukan dengan Rancangan Acak Lengkap (RAL) dengan lima perlakuan, yaitu strain larva dan tiga ulangan. Larva udang galah stadia 4 dari 5 populasi berbeda, dengan panjang rata-rata 2,7 $\pm 0,4 \mathrm{~mm}$ ditempatkan di stoples volume $3 \mathrm{~L}$ dengan padat penebaran larva 100 ekor/L. Setiap wadah diisi $1 \mathrm{~L}$ air payau $10 \%$. Selanjutnya diinfeksi bakteri $V$. harveyi patogen berumur 24 jam dengan kepadatan $10^{5} \mathrm{cfu} / \mathrm{mL}$. Nauplii Artemia diberikan pada pagi dan sore hari. Parameter yang diamati meliputi pengamatan visual abnormalitas larva uji yang dilihat dari tingkah laku larva dan kondisi organ hepatopankreas, tingkat sintasan, kelimpahan total bakteri Vibrio sp. dan V. harveyi, identifikasi bakteri, dan parameter kualitas air. Selama 48 jam perlakuan sintasan larva yang berasal dari strain induk yang berbeda memberikan hasil berbeda nyata dengan tingkat sintasan tertinggi pada larva asal Barito, yaitu 75\%; diikuti GIMacro 65\%; Asahan 61,33\%; Ciasem 53,66\%; strain Ogan 20\%.
\end{abstract}

KATA KUNCl: ketahanan, larva udang galah, varietas unggul, Vibrio harveyi

ABSTRACT: Resistance of giant freshwater prawn larva collected from different locations to Vibrio harveyi. By: Ikhsan Khasani, Dinamella Wahjuningrum, and Yan Evan

Vibriosis caused by Vibrio harveyi is a serious problem in intensive system hatcheries of freshwater prawn. This study was conducted to study the resistance of larvae from different locations i.e. Ogan River, South Sumatra; Asahan River, North Sumatra; Barito River, South Kalimantan; Ciasem River, West Java; and GIMacro, as part of breeding program to create superior prawn strain. Complete randomized design was used in this study, with 5 treatments, i.e. larvae source and 3 replications. $4^{\text {th }}$ stage of freshwater prawn larvae from the different populations, average total length of $2,7 \pm 0,4 \mathrm{~mm}$, were reared in 3 liters buckets with larvae density of 100 larvae/L. Each bucket was filled with $1 \mathrm{~L}$ of $10 \%$ saline water. V. harveyi aged 24 hours was inoculated in each bucket with a density of $10^{5} \mathrm{cfu} / \mathrm{mL}$. Artemia sp. nauplii was given to the larvae twice per day. Some parameters consisting of abnormalitas of larvae, larvae behaviour, hepatopancreas performance, mortality, total of Vibrio sp. number and water quality was observed during the study. During 48 hours of the treatment, 
showed that factor of different larvae location gave a significant result to larvae survival rate. The highest survival rates was observed in the Barito larvae population (75\%), followed by GIMacro (65\%), Asahan (61.33\%), Ciasem (53.66\%), and Ogan $20 \%$.

\section{KEYWORDS: prawn larvae, resistance, superior strain, Vibrio harveyi}

\section{PENDAHULUAN}

Udang galah (Macrobrachium rosenbergii de Man) merupakan salah satu komoditas air tawar yang prospektif dikembangkan sebagai komoditas budidaya, dan merupakan udang air tawar dengan capaian ukuran terbesar sehingga berpotensi sebagai komoditas ekspor. Dalam rangka meningkatkan produksi udang galah nasional, ketersediaan induk, dan benih unggul menjadi prasyarat mutlak, sehingga tercipta sistem budidaya yang produktif dan kompetitif. Salah satu karakter unggul yang selalu dinanti pembudidaya adalah udang dengan pertumbuhan cepat dan tahan dengan tekanan kualitas air sehingga dapat dibudidayakan secara intensif dengan kepadatan tinggi. Dalam rangka penyediaan induk unggul tersebut, maka serangkaian program riset pemuliaan, baik melalui jalur seleksi maupun hibridisasi inter spesies telah dan sedang dilaksanakan, khususnya di Loka Riset Pemuliaan dan Teknologi Budidaya Perikanan Air Tawar.

Indonesia memiliki potensi untuk perbaikan genetik udang galah melalui jalur hibridisasi, karena populasi udang galah di Indonesia melimpah dan bersifat unik. Berdasarkan distribusi geografisnya dapat diprediksi bahwa Indonesia menjadi centre of origin dari udang galah karena terdapat 19 spesies dari marga Macrobrachium (Hadie \& Hadie, 2002). Variasi kondisi habitat populasipopulasi udang galah tersebut, seperti lahan gambut dengan karakter $\mathrm{pH}$ rendah, Sungai Barito dengan karakter kadar phyrite $\left(\mathrm{Fe}^{2+}\right)$ tinggi, dan populasi Sungai Ciasem dengan tekanan limbah domestik, membuka harapan untuk mendapatkan hibrid udang galah dengan performa pertumbuhan cepat dan daya adaptasi terhadap lingkungan ekstrim.

Fase awal pada makhluk hidup, termasuk udang galah merupakan fase yang kritis dan sangat penting. Dalam budidaya, keberhasilan suatu spesies untuk melewati fase awal (larva) merupakan suatu indikator keunggulan, karena populasi yang berhasil melewati fase larva berpeluang besar untuk hidup dan tumbuh hingga dewasa. Salah satu masalah pada pembenihan udang intensif secara umum adalah timbulnya penyakit yang disebabkan oleh bakteri, seperti Vibrio sp., Aeromonas sp., Pseudomonas sp., dan Edwardsiella sp. Dalam budidaya, keberhasilan suatu spesies untuk melewati fase larva merupakan suatu indikator keunggulan, karena populasi yang berhasil melewati fase ini akan berpeluang lebih besar untuk hidup, tumbuh, dan berkembang sampai dewasa. Kematian larva yang tinggi tidak hanya disebabkan oleh faktor lingkungan saja, tetapi juga oleh infeksi penyakit. Menurut Tonguthai (1997), larva udang galah stadia awal sangat mudah terinfeksi penyakit vibriosis yang disebabkan oleh bakteri Vibrio harveyi.

Udang galah pada fase tersebut membutuhkan media air payau sehingga pada fase larva sangat rentan terinfeksi bakteri $V$. harveyi, yang merupakan patogen utama pada pembenihan udang laut. Banyak diinformasikan pada kegiatan pembenihan udang galah sering terjadi kasus infeksi penyakit vibriosis yang disebabkan oleh bakteri Vibrio spp. (Supriyadi et al., 2001). Penyakit bakterial yang disebabkan oleh bakteri dari genus Vibrio sering kali menjadi faktor pembatas dalam proses budidaya (Huervana et al., 2006). Bakteri Vibrio sp. bersifat ubiquitous dan merupakan mikroorganisme yang banyak terdapat dalam lingkungan budidaya udang (Sharshar \& Azab, 2008).

Selama ini cara yang umum untuk menanggulangi penyakit yang disebabkan bakteri $V$. harveyi di hatcheri udang adalah dengan menggunakan antibiotik. Akan tetapi, cara tersebut memiliki dampak negatif terhadap keseimbanganekosistem, sehingga perlu alternatif lain yang efektif dan ramah lingkungan. Dikarenakan Indonesia memiliki berbagai strain udang galah yang tersebar berdasarkan letak geografisnya, maka uji potensi beberapa strain udang galah tersebut, khususnya uji tingkat ketahanan terhadap kondisi ekstrim selama budidaya perlu dilakukan. 
Berdasarkan uraian tersebut, telah dilakukan penelitian. Penelitian ini bertujuan untuk mengetahui tingkat ketahanan beberapa strain larva udang galah, yaitu Sungai Ogan, Sumatera Selatan; Sungai Asahan, Sumatera Utara; Sungai Barito, Kalimantan Selatan; Sungai Ciasem, Jawa Barat; dan strain GIMacro terhadap bakteri Vibrio harveyi, sebagai dasar perakitan varietas unggul udang galah.

\section{BAHAN DAN METODE}

Penelitian dilaksanakan di Loka Riset Pemuliaan dan Teknologi Budidaya Perikanan Air Tawar, Sukamandi-Subang untuk pelaksanaan pemijahan beberapa strain induk udang galah dan Laboratorium Kesehatan Ikan Jurusan Budidaya Perairan, FPIK-IPB untuk pelaksanaan perlakuan uji ketahanan larva udang galah. Bahan biologis yang digunakan adalah udang galah dari lima sumber populasi, yaitu asal Sungai Ogan, Sumatera Selatan; asal induk Sungai Barito, Kalimantan Selatan; asal Sungai Asahan, Sumatera Utara; asal Sungai Ciasem, Jawa Barat; dan varietas GIMacro.

\section{Penyiapan dan Penanganan Larva Udang Galah}

Setiap strain induk udang galah diseleksi untuk mencari induk yang sehat dan matang gonad, kemudian induk dipijahkan pada masing-masing bak pemijahan. Setiap hari dilakukan pengamatan untuk mendapatkan larva dari induk-induk lima populasi yang telurnya menetas secara bersamaan. Larvalarva tersebut dipanen dan dipilih yang sehat. Larva yang diperoleh disterilkan dengan cara perendaman dalam larutan formaldehide dosis $200 \mathrm{~mL} / \mathrm{L}$ selama 30 detik. Kemudian larva dipelihara secara terpisah sesuai dengan populasinya. Setelah itu, larva siap dilakukan uji ketahanan terhadap bakteri Vibrio herveyi.

Larva udang galah yang digunakan sebagai organisme uji adalah larva udang galah stadia 4 dengan panjang rata-rata $2,7 \pm 0,4 \mathrm{~mm}$. Padat penebaran larva adalah 100 ekor/L. Pakan nauplii Artemia sp. diberikan pada pagi pukul 08.00 WIB dan sore hari pada pukul 16.00 WIB, kebutuhan larva per hari sebanyak kurang lebih 10 ekor nauplii Artemia sp. Wadah yang digunakan untuk pemeliharaan dan perlakuan larva udang galah adalah stoples bervolume 3 L (Lampiran 8). Setiap wadah diisi air payau 10\% sebanyak 1 L. Pemasangan aerasi dilakukan untuk mempertahankan kadar oksigen di atas $5 \mathrm{mg} / \mathrm{L}$.

\section{Isolat Bakteri Vibrio harveyi}

Vibrio harveyi patogen yang digunakan merupakan koleksi Balai Riset Perikanan Budidaya Air Payau, Maros-Sulawesi Selatan. Bakteri tersebut diisolasi dari udang yang terinfeksi penyakit vibriosis. Selanjutnya, biakan diinkubasi pada suhu ruang $28^{\circ} \mathrm{C}-31^{\circ} \mathrm{C}$ selama 24 jam dalam media SWC (Sea Water Complete) (Lampiran 1) dan TCBS (Thiosulphate Citrate Bile-salt Sucrose) (Lampiran 1) kemudian dilihat koloni yang berpendar. Koloni yang terpisah dan berpendar dipilih secara acak untuk dimurnikan lebih lanjut.

\section{Pengukuran Konsentrasi Bakteri}

Pengukuran konsentrasi bakteri $V$. harveyi dilakukan untuk mengetahui kepadatan bakteri/mL, sehingga dapat diketahui berapa banyak bakteri yang harus diambil untuk dosis yang diberikan. Pengukuran konsentrasi bakteri dilakukan dengan menggunakan spektrofotometer dan hasil yang didapat dibandingkan dengan hasil dari perhitungan metode cawan sebar dari hasil pengenceran seri. Sebelum dilakukan pengukuran OD (optical density), bakteri $V$. harveyi dikultur selama 24 jam pada media SWC cair dan disimpan dalam shaker-inkubator pada suhu $28^{\circ} \mathrm{C}$ supaya bakteri tumbuh secara optimal. Setelah 24 jam, bakteri diambil untuk dilakukan pengukuran OD dengan menggunakan spektrofotometer pada panjang gelombang 600 A. Selain itu, dilakukan pengenceran serial terhadap bakteri tersebut untuk metode cawan sebar (Bibiana, 1994; Collins et al., 1995).

\section{Air Media Pemeliharaan Larva}

Air laut yang digunakan untuk pemeliharaan larva udang galah selama penelitian adalah air laut steril, yang disterilisasi dengan menggunakan autoklaf pada suhu $121^{\circ} \mathrm{C}$ tekanan 1 atm selama 15 menit. Selanjutnya, dilakukan pengenceran dengan air tawar steril, guna memperoleh air payau bersalinitas $10 \%$, yang merupakan salinitas optimal untuk kehidupan dan pertumbuhan larva udang galah (Aquacop, 1983).

\section{Metode Perlakuan}

\section{Uji LD 50}

Pada uji ini terdapat 6 perlakuan perendaman isolat bakteri $V$. harveyi ke dalam 
media pemeliharaan, yaitu pada konsentrasi $10^{4}, 10^{5}, 10^{6}, 10^{7}, 10^{8} \mathrm{cfu} / \mathrm{mL}$, dan kontrol (tanpa penambahan bakteri). Masing-masing perlakuan diulang 3 kali. Larva yang digunakan untuk uji LD $_{50}$ adalah larva GIMacro stadia 4. Pengamatan dilakukan setiap 12 jam selama 2 hari terhadap jumlah larva yang mati, morfologi, dan tingkah laku larva dibandingkan dengan kontrol. Selanjutnya untuk perhitungan estimasi $\mathrm{LD}_{50}$ menggunakan metode Karber 1931 (Reed \& Muench, 1938).

\section{Uji tantang}

Sebanyak 100 ekor masing-masing larva uji dari lima strain dimasukkan ke dalam stoples berisi $1 \mathrm{~L}$ media 10\%. Masing-masing perlakuan uji tantang diulang tiga kali. Ke dalam tiap stoples tersebut selanjutnya diinfeksikan bakteri $V$. harveyi patogen berumur 24 jam dengan kepadatan $10^{5} \mathrm{cfu} / \mathrm{mL}$ hasil dari uji $\mathrm{LD}_{50}$ (Lampiran 5). Pengamatan dilakukan terhadap sintasan dan abnormalitas larva setiap 12 jam selama dua hari (48 jam). Pada malam hari juga dilakukan pengamatan untuk melihat apakah kematian larva benar disebabkan oleh $V$. harveyi bercahaya. Larva yang terinfeksi $V$. harveyi bercahaya mudah diamati pada malam hari (kondisi gelap) sebab larva tersebut akan terlihat bercahaya.

\section{Perhitungan populasi Vibrio harveyi dalam tubuh larva}

Perhitungan bakteri $V$. harveyi dalam tubuh larva dilakukan pada awal dan akhir pemeliharaan. Satu ekor diambil dari tiap wadah, kemudian dimasukkan ke dalam eppendorf steril yang berisi air payau steril. Selanjutnya, larva digerus dan dilakukan pengenceran serial dan hasil pengenceran serial disebar pada media TCBS (Thiosulphate Citrate Bile-salt Sucrose).

\section{Rancangan Percobaan}

Penelitian menggunakan rancangan acak lengkap (RAL) dengan lima perlakuan, berupa strain larva udang galah, dan masing-masing diulang tiga kali, yaitu:

PerlakuanA: Asal induk Sungai Ogan, Sumatera Selatan

Perlakuan B : Asal induk Sungai Barito, Kalimantan Selatan

Perlakuan C: Asal induk Sungai Asahan, Sumatera Utara
Perlakuan D : Asal induk Sungai Ciasem, Jawa Barat

Perlakuan E : Asal induk varietas GIMacro

\section{Model Percobaan}

Model yang digunakan dalam penelitian adalah (Steel \& Torrie, 1982):

$$
Y i j=\mu+\sigma i+\varepsilon i j
$$

di mana:

$Y_{i j}=$ Data hasil pengamatan pada perlakuan kei dan ulangan ke-j (Data of observation treat)

$\mu=$ Nilai tengah dari pengamatan (Mean values of the data)

$\sigma i=$ Pengaruh aditif dari perlakuan ke-i (Additive effect of treatment $j$ )

$\varepsilon i j=$ Pengaruh galat hasil percobaan pada perlakuan ke-i dan ulangan ke-j (Bias effect of the experiment on treatment $j$ and replication i)

Ada atau tidaknya perbedaan antar perlakuan dilihat pada hasil analisis ragam (ANOVA) dengan uji F pada selang kepercayaan 95\%. Apabila berpengaruh nyata, untuk melihat perbedaan antar perlakuan diuji lanjut dengan menggunakan uji Duncan pada selang kepercayaan 95\%. Data sintasan larva yang diperoleh kemudian ditabulasi dan dianalisis dengan menggunakan program Microsoft Office Excel 2007 dan SPSS ver.15. Parameter abnormalitas larva dan identifikasi bakteri menggunakan analisis deskripsi kualitatif dan untuk parameter kelimpahan total bakteri dan kualitas air menggunakan analisis deskripsi kuantitatif.

\section{Pengamatan Visual Abnormalitas Larva Uji}

Pengamatan secara visual dilakukan untuk mengamati tingkah laku dan perubahan morfologi yang terjadi pada larva uji. Pengamatan dilakukan setelah larva diinfeksi bakteri melalui perendaman (dipping) pada media pemeliharaan, yang diamati setiap 12 jam selama 48 jam.

Pengamatan yang dilakukan meliputi perubahan warna tubuh, perpendaran (menyala) pada tubuh larva udang yang terinfeksi bakteri, nafsu makan, pergerakan larva, dan kondisi hepatopankreas. Hasil pengamatan dilakukan untuk mengetahui gejala klinis larva yang terinfeksi bakteri $V$. harveyi secara visual. 
Pengamatan respons terhadap artemia yang diberikan dilihat dari sisa artemia yang tidak dimakan dan diklasifikasikan sebagai berikut:

1. Sangat responsif $(++++)=$ Tidak ada sisa artemia

2. Responsif $(+++)=$ Sisa artemia sebanyak $10 \%$

3. Kurang responsif $(++)=$ Sisa artemia sebanyak $50 \%$

4. Tidak responsif $(+)=$ Sisa artemia sebanyak $80 \%-100 \%$

Sedangkan pergerakan larva pasca infeksi diklasifikasikan sebagai berikut:

1. Berenang normal $(+++)=$ Larva berenang di dinding kolom air

2. Berenang tanpa arah $(++)=$ Larva berenang tidak beraturan

3. Berenang lemah di dasar $(+)=$ Sebagian besar larva berenang di dasar

\section{Sintasan Larva Udang}

Sintasan larva udang dihitung dengan menggunakan rumus sesuai Goddard (1996) \& Zonneveld et al. (1991):

$$
\mathrm{SR}=\frac{\mathrm{Nt}}{\mathrm{No}} \times 100 \%
$$

di mana:

$\mathrm{SR}=$ Sintasan (\%) (Survival rate)

$\mathrm{Nt}=$ Jumlah larva udang yang hidup pada akhir pengamatan (ekor) (Number of survived larvae at the end of the experiment (ind.))

No = Jumlah larva udang pada awal pengamatan (Initial number of larvae)

\section{Kelimpahan Total Bakteri (Vibrio sp. dan V. harveyi)}

Kelimpahan total bakteri pada media pemeliharaan dan larva dihitung menggunakan metode hitungan cawan sebar dengan perhitungan sebagai berikut (Hadioetomo, 1993):

$$
\Sigma \text { bakteri }=\mathrm{N} \times \frac{1}{\mathrm{f}} \times \frac{1}{\Sigma \text { penebaran }}
$$

di mana

$\Sigma$ bakteri $=$ Banyaknya sel bakteri $(\mathrm{cfu} / \mathrm{mL})($ Total bacteria population)

$\mathrm{N}=$ Jumlah koloni bakteri (Number of bacteria colonies)

\section{Identifikasi Bakteri}

Langkah awal prosedur identifikasi bakteri pada penelitian ini adalah dengan menumbuhkan isolat bakteri pada media TCBS, hal ini untuk mengetahui bakteri sampai tingkat genus. Koloni bakteri Vibrio sp. pada media TCBS akan berwarna hijau dan berpendar, sedangkan untuk koloni berwarna kuning bakteri V. Harveyi. Langkah selanjutnya, dilakukan uji pewarnaan gram untuk mengetahui sifat gram dan bentuk bakteri. Sedangkan untuk identifikasi bakteri sampai tingkat spesies menggunakan analisis fisiologis Microgen ${ }^{\mathrm{TM}}$ Gn A+B-ID sistem. Hasil identifikasinya selanjutnya dicocokan dengan Bergey's Manual Holt et al. (1994).

\section{Pengukuran Parameter Kualitas Air}

Parameter kualitas air yang diukur meliputi DO (oksigen terlarut), suhu, pH, salinitas, kadar amonia dan kadar nitrit. Pengukuran kualitas air dilakukan pada awal dan akhir pemeliharaan. Pengukuran DO, suhu, dan $\mathrm{pH}$ menggunakan alat digital yaitu water quality checker Horiba. Pengukuran salinitas dengan refraktometer. Pengukuran parameter amonia dengan metode phenate dan nitrit dengan metode sulfanilamid, dan diukur menggunakan spektrofotometer (Clesceri et al., 1989; APHA, 2005).

\section{HASIL DAN BAHASAN}

\section{Abnormalitas Larva Uji Berdasarkan Tingkah Laku Larva dan Kondisi Organ Hepatopankreas}

Selama penelitian dilakukan pengamatan performa larva udang galah secara visual, walaupun dengan pengamatan yang sangat terbatas. Hal tersebut karena ukuran larva udang galah yang sangat kecil, yaitu stadia 4 dengan panjang rata-rata $2,7 \pm 0,4 \mathrm{~mm}$. Hasil pengamatan visual terhadap larva udang galah yang terinfeksi terlihat gejala stres, seperti nafsu makan rendah dengan indikasi kurang responsif terhadap Artemia yang diberikan (Tabel 1); pergerakan larva tidak normal (Tabel 2); hepatopankreas terlihat pucat dan hancur; serta sampai terjadi perubahan warna tubuh pada larva yang terinfeksi bakteri $V$. harveyi. Pada Gambar 1 terlihat perbedaan kondisi hepatopankreas normal dan hepatopankreas yang abnormal akibat infeksi $V$. harveyi. 

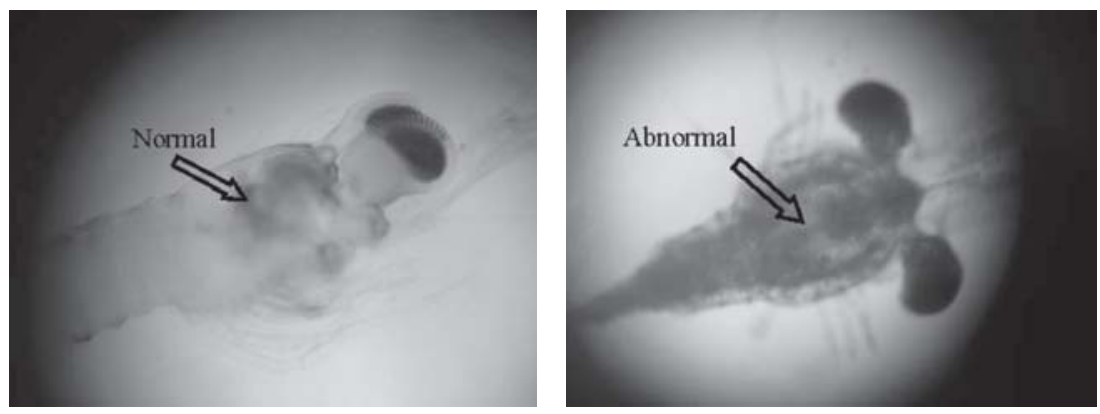

Gambar 1. Gambaran kondisi hepatopankreas larva udang galah (kiri: hepatopankreas normal, terlihat utuh; kanan: hepatopankreas terinfeksi $V$. harveyi, terlihat hancur, dan pucat)

Figure 1. Visual condition of freshwater prawn larvae hepatopancreas (left: normal, intack; right: abnormal, broken, and pallness)

Salah satu gejala awal larva yang terinfeksi patogen adalah nafsu makan berkurang, sehingga kondisi larva semakin lemah dan berpotensi besar menyebabkan larva mati. Tabel 1 merupakan gambaran kondisi larva dari sumber populasi berbeda setelah terinfeksi bakteri $V$. harveyi.

Larva udang galah setelah diinfeksi bakteri $V$. harveyi $10^{5} \mathrm{cfu} / \mathrm{mL}$ ke dalam media pemeliharaan menunjukkan gejala stres dengan berenang tanpa arah (Tabel 2), nafsu makan rendah terlihat dari kurang responsif terhadap Artemia (Tabel 1), larva yang transparan berubah menjadi putih pucat, dan pada malam hari larva terlihat berkunang-kunang. Kondisi hepatopankreas pada larva yang terinfeksi juga terlihat rusak dan menyebar, berbeda dengan kondisi hepatopankreas normal (Gambar 1). Menurut Huervana et al. (2006), organ target infeksi $V$. harveyi adalah hepatopankreas, terlihat peradangan yang menyebar di semua bagian hepatopankreas. Hepatopankreas merupakan kelenjar pencernaan yang berfungsi untuk memproduksi enzim pencernaan dan mengasimilasi nutrien, termasuk pula menyerap makanan, trans-

Tabel 1. Respons larva pasca infeksi terhadap pakan (Artemia)

Table 1. Feeding activity of larvae after infected

\begin{tabular}{lccc}
\hline \multirow{1}{*}{$\begin{array}{c}\text { Perlakuan } \\
\text { Treatments }\end{array}$} & \multicolumn{3}{c}{$\begin{array}{c}\text { Hasil pengamatan } \\
\text { Observation result }\end{array}$} \\
\cline { 2 - 4 } & $\begin{array}{c}\text { Ulangan 1 } \\
\text { Replicate 1 }\end{array}$ & $\begin{array}{c}\text { Ulangan 2 } \\
\text { Replicate 2 }\end{array}$ & $\begin{array}{c}\text { Ulangan 3 } \\
\text { Replicate 3 }\end{array}$ \\
\hline Strain Ogan (Ogan strain) & + & + & ++ \\
Strain Barito (Barito strain) & +++ & +++ & ++ \\
Strain Asahan (Asahan strain) & ++ & ++ & +++ \\
Strain Ciasem (Ciasem strain) & ++ & ++ & ++ \\
Strain GIMacro (GIMacro strain) & ++ & +++ & ++ \\
Kontrol (Control) & ++++ & ++++ & ++++ \\
\hline
\end{tabular}

Keterangan (Notes):

$++++=$ Sangat responsif (Highly responsive)

$++=$ Responsif (Responsive)

$++\quad=$ Kurang responsif (Low responsive)

$+\quad=$ Tidak responsif (No response) 
Uji ketahanan larva udang galah dari beberapa ..... (Ikhsan Khasani)

Tabel 2. Pola pergerakan larva pasca infeksi bakteri $V$. harveyi

Table 2. Motion pattern of larvae after infected with $\boldsymbol{V}$. harveyi

\begin{tabular}{lccc}
\hline \multirow{2}{*}{$\begin{array}{c}\text { Perlakuan } \\
\text { Treatments }\end{array}$} & \multicolumn{3}{c}{$\begin{array}{c}\text { Hasil pengamatan } \\
\text { Observation result }\end{array}$} \\
\cline { 2 - 4 } & $\begin{array}{c}\text { Ulangan 1 } \\
\text { Replicate 1 }\end{array}$ & $\begin{array}{c}\text { Ulangan 2 } \\
\text { Replicate 2 }\end{array}$ & $\begin{array}{c}\text { Ulangan 3 } \\
\text { Replicate 3 }\end{array}$ \\
\hline Strain Ogan (Ogan strain) & + & ++ & + \\
Strain Barito (Barito strain) & +++ & +++ & ++ \\
Strain Asahan (Asahan strain) & ++ & + & ++ \\
Strain Ciasem (Ciasem strain) & ++ & + & ++ \\
Strain GIMacro (GIMacro strain) & ++ & ++ & + \\
Kontrol (Control) & +++ & +++ & +++ \\
\hline
\end{tabular}

Keterangan (Notes):

+++ = Larva berenang normal (Larvae swim normally);

$++\quad=$ Larva berenang tanpa arah (Larvae swim abnormal);

$+\quad=$ Larva berenang lemah di dasar (Larvae swim weakly in bottom)

portasi, sekresi dari enzim pencernaan, serta menyimpan lemak, glikogen, dan beberapa mineral (Harrison \& Humes, 1992 dalam Taufik et al., 2001). Jika organ hepatopankreas terganggu maka akan menggangu sistem fisiologis larva udang galah sehingga akhirnya dapat menyebabkan kematian.

Selain berakibat terhadap menurunnya aktivitas makan (feeding) larva, dampak infeksi bakteri patogen terhadap larva pada tingkat awal juga menyebabkan gerakan larva tidak normal. Larva udang galah secara alami bersifat planktonik, aktif bergerak mundur di permukaan media. Pada Tabel 2 ditampilkan kondisi gerakan larva udang galah setelah diinfeksi bakteri $V$. harveyi. Pada Tabel 2 tersebut terlihat bahwa larva udang galah strain Barito masih bergerak normal sebagaimana kondisi pada kontrol, yang mengindikasikan bahwa infeksi bakteri patogen belum berdampak terhadap pola pergerakan larva. Berdasarkan hal tersebut dapat dinyatakan bahwa strain Barito lebih tahan terhadap infeksi $V$. harveyi. Sementara itu, pergerakan larva pada keempat strain lainnya sudah mulai terganggu, dengan indikasi larva bergerak tanpa arah, dan melemah di dasar wadah.

\section{Sintasan Larva}

Pengaruh inokulasi bakteri $V$. harveyi dengan dosis $10^{5} \mathrm{cfu} / \mathrm{mL}$ pada media pemeliharaan terhadap sintasan larva udang galah dari sumber populasi yang berbeda dituangkan pada Gambar 2. Sintasan larva yang berasal dari strain induk yang berbeda memberikan hasil sebagai berikut: strain Ogan 20\%; strain Ciasem 53,66\%; strain Asahan $61,33 \%$; strain GIMacro 65\%; dan strain Barito $75 \%$. Hasil uji statistik pada selang kepercayaan 95\% menunjukkan bahwa secara keseluruhan terdapat perbedaan yang nyata terhadap sintasan antara kontrol dengan perlakuan. Larva strain Barito memiliki sintasan tertinggi jika dibandingkan dengan perlakuan lainnya yaitu sebesar $75 \%$, sedangkan tingkat sintasan terendah pada perlakuan larva strain Ogan sebesar $20 \%$.

Larva udang yang terinfeksi bakteri $V$. harveyi akan mengalami gejala klinis serta abnormalitas pada organ target sehingga pada akhirnya dapat menyebabkan kematian, dan kematian tersebut akan berdampak pada sintasan larva yang rendah selama pembenihan. Tingkat sintasan tertinggi antara perlakuan diperoleh pada larva udang galah strain Barito, yaitu sebesar 75\%, sedangkan tingkat sintasan terendah terjadi pada larva strain Ogan, yaitu sebesar 20\% (Gambar 2). Hasil uji statistik pada selang kepercayaan $95 \%$ menunjukkan bahwa secara keseluruhan terdapat perbedaan yang nyata terhadap sintasan antara kontrol dengan perlakuan. Dari hasil uji dapat dikatakan bahwa perbedaan asal induk udang galah menghasilkan larva dengan kualitas ketahanan terhadap bakteri $V$. harveyi 


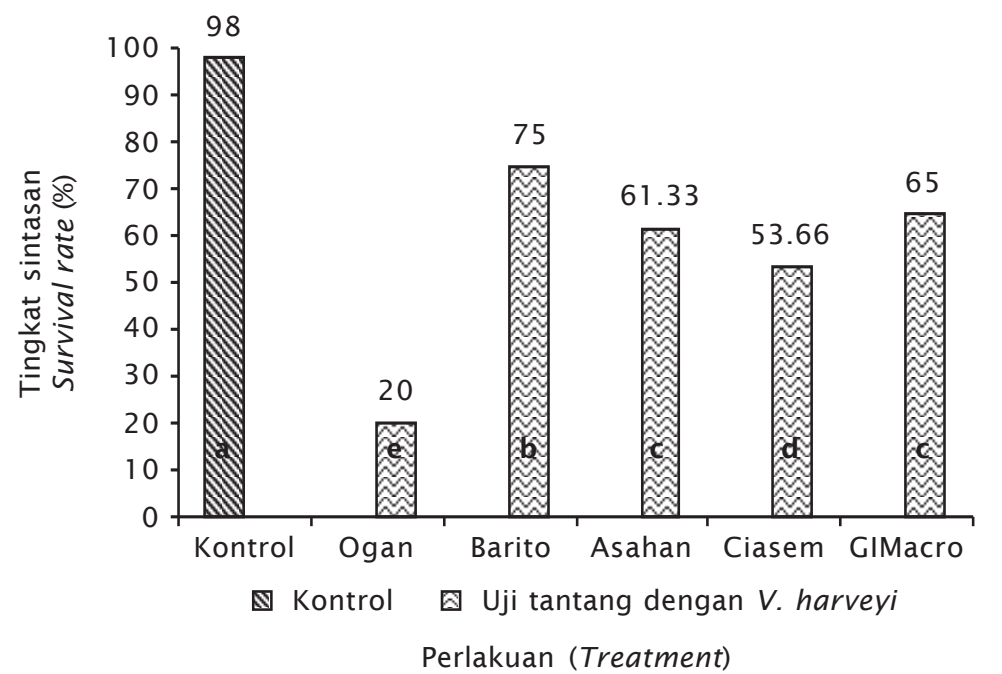

Keterangan: Huruf yang berbeda di dalam grafik menunjukkan hasil yang berbeda nyata $(P<0,05)$

Note: Different alphabets in the graphic indicate significant result $(P<0.05)$

Gambar 2. Sintasan setiap strain larva udang galah

Figure 2. Survival rate of the different strains of prawn larvae

yang berbeda. Pola distribusi geografis udang galah yang tersebar di Indonesia banyak berkaitan dengan aspek toleransi fisiologis (Praseno et al., 2001).

Pada Gambar 2 terlihat bahwa penambahan bakteri $V$. harveyi $10^{5} \mathrm{cfu} / \mathrm{mL}$ ke dalam media pemeliharaan sangat mempengaruhi sintasan larva. Hal ini diduga karena penambahan bakteri $V$. harveyi ke dalam media pemeliharaan telah mengganggu keseimbangan mikroba dalam tubuh larva dan pada konsentrasi bakteri $V$. harveyi $10^{5} \mathrm{cfu} / \mathrm{mL}$ dengan proses perendaman merupakan jumlah (quorum) minimal yang dibutuhkan untuk mengekspresikan faktor-faktor virulensinya sehingga dapat menyebabkan kematian pada larva udang galah. Hoa et al. (2006) menyatakan bahwa beberapa isolat bakteri akan bersifat patogen terhadap larva udang pada konsentrasi $10^{5}-10^{7} \mathrm{sel} / \mathrm{mL}$ dan akan mempengaruhi sintasan larva setelah 24-48 jam pasca infeksi dengan cara perendaman. Jika dilihat dari nilai sintasan, larva udang galah asal Barito memperlihatkan performa yang cukup baik dari segi ketahanan tubuh terhadap infeksi $V$. harveyi $10^{5} \mathrm{cfu} / \mathrm{mL}$ selama 48 , dengan tingkat sintasan yang cukup tinggi sebesar 75\%. Dapat disimpulkan bahwa udang galah asal Barito memiliki sifat unggul dari segi ketahanan terhadap bakteri $V$. harveyi.

\section{Kelimpahan Total Bakteri Vibrio sp. dan Vibrio harveyi}

Guna mengetahui bahwa bakteri $V$. harveyi yang diinokulasikan dapat hidup dalam media uji, telah dilakukan penghitungan total bakteri Vibrio. Pada Tabel 3 terlihat terjadi penurunan kelimpahan total bakteri untuk semua perlakuan bila dibandingkan antara awal dan akhir perlakuan. Hasil kelimpahan total bakteri Vibrio sp. dan $V$. harveyi pada awal infeksi untuk setiap perlakuan rata-rata berkisar $10^{5} \mathrm{cfu} / \mathrm{mL}$, sedangkan pada saat akhir perlakuan kelimpahan total bakteri rata-rata berkisar $10^{3}-10^{4}$ $\mathrm{cfu} / \mathrm{mL}$. Berbeda dengan perlakuan, hasil kelimpahan total bakteri Vibrio sp. dan $V$. harveyi pada kontrol menunjukkan tidak terdeteksinya bakteri Vibrio sp. dan V. harveyi pada saat awal pemeliharaan, sedangkan pada akhir pemeliharaan kelimpahan bakteri Vibrio sp. adalah 5,2 × $10^{3} \mathrm{cfu} / \mathrm{mL}$ dan kelimpahan bakteri $V$. harveyi tidak terdeteksi.

Penurunan kelimpahan total bakteri untuk semua perlakuan bila dibandingkan antara awal dan akhir perlakuan, hal tersebut diduga 
Tabel 3. Kelimpahan total bakteri Vibrio sp. dan Vibrio harveyi pada media pemeliharaan larva selama perlakuan

Table 3. Total bacteria abundance, Vibrio sp. and Vibrio harveyi, in the larvae rearing media during treatment

\begin{tabular}{lccc}
\hline $\begin{array}{c}\text { Perlakuan } \\
\text { Treatments }\end{array}$ & $\begin{array}{c}\text { Wakt u } \\
\text { Time }\end{array}$ & $\begin{array}{c}\text { Vibrio sp. } \\
(\mathrm{cfu} / \mathrm{mL})\end{array}$ & $\begin{array}{c}\text { Vibrio harveyi } \\
(\mathrm{cfu} / \mathrm{mL})\end{array}$ \\
\hline Strain Ogan (Ogan strain) & $\begin{array}{c}\text { Awal (initial) } \\
\text { Akhir (final) }\end{array}$ & $\begin{array}{c}10^{5} \\
9.6 \times 10^{4}\end{array}$ & $\begin{array}{c}10^{5} \\
5.4 \times 10^{4}\end{array}$ \\
\hline Strain Barito (Barito strain) & Awal (initial) & $10^{5}$ & $10^{5}$ \\
& Akhir (final) & $3.3 \times 10^{4}$ & $3.2 \times 10^{4}$ \\
\hline Strain Asahan (Asahan strain) & Awal (initial) & $10^{5}$ & $10^{5}$ \\
& Akhir (final) & $8.1 \times 10^{3}$ & $7.8 \times 10^{3}$ \\
\hline Strain Ciasem (Ciasem strain) & Awal (initial) & $10^{5}$ & $10^{5}$ \\
& Akhir (final) & $1.8 \times 10^{4}$ & $1.7 \times 10^{5}$ \\
\hline Strain GIMacro (GIMacro strain) & Awal (initial) & $10^{5}$ & $10^{5}$ \\
& Akhir (final) & $6.9 \times 10^{3}$ & $6.6 \times 10^{3}$ \\
\hline Kontrol (Control) & Awal (initial) & $\mathrm{TT}$ & $\mathrm{TT}$ \\
& Akhir (final) & $5.2 \times 10^{3}$ & $\mathrm{TT}$ \\
\hline
\end{tabular}

Keterangan (Note): TT = Tidak terdeteksi $($ Undetected $)$

terjadi karena bakteri menginfeksi ke dalam tubuh larva atau bakteri mati karena lingkungan media hidupnya kurang optimal. Selain bakteri $V$. harveyi terdapat bakteri jenis lain pada media pemeliharaan ditandai dengan warna koloni kuning, sedangkan koloni $V$. harveyi pada media TCBS berwarna hijau. Bakteri tersebut diduga berasal dari dalam tubuh larva udang galah yang secara alami sudah ada atau kemungkinan lain berasal dari artemia yang diberikan untuk pakan larva udang galah

Pada Tabel 4 disajikan rata-rata kelimpahan bakteri $V$. harveyi dalam tubuh larva udang yang mengalami kematian, untuk setiap perlakuan. Kelimpahan bakteri $V$. harveyi pada larva yang mati berkisar 102-10 $0^{3} \mathrm{cfu} /$ larva, sedangkan bakteri $V$. harveyi pada larva hidup wadah kontrol tidak terdeteksi.

Jumlah bakteri $V$. harveyi yang ditemukan pada larva yang mati untuk setiap perlakuan relatif sama yaitu berkisar antara $10^{2}-10^{3} \mathrm{cfu} /$ larva. Kisaran nilai tersebut menunjukkan jumlah sel bakteri yang dapat menyebabkan kematian pada larva udang galah. Hal ini diperkuat dari hasil penelitian Widanarni (2004), jumlah V. harveyi yang ditemukan pada larva yang mati berkisar antara $10^{2}-10^{3} \mathrm{cfu} /$ larva. Vibrio harveyi adalah salah satu spesies dari genus Vibrio yang bersifat patogenik terhadap larva udang galah dan menyebabkan kematian sebesar 18\%-80\% dalam 48 jam (Hoa et al., 2006).

\section{Identifikasi Bakteri}

Untuk memastikan jenis bakteri yang terdapat pada larva udang yang mati dilakukan reisolasi larva yang terinfeksi. Hasil identifikasi tersebut membuktikan bahwa larva udang galah yang mati positif terinfeksi bakteri $V$. harveyi. Hasil identifikasi bakteri pada larva yang mati dengan pewarnaan gram diperoleh bakteri bersifat gram negatif dan berbentuk batang. Selain itu, bakteri tumbuh pada media TCBS serta jika diamati pada kondisi gelap bakteri tersebut berpendar. Kemampuan berpendar merupakan hasil aktivitas enzim luciferase yang dapat berfungsi sebagai katalisator dalam proses oksidasi reduksi. Proses oksidasi melibatkan flavin mononukleotida dan aldehid alifatik rantai panjang sebagai substratnya (Meighen, 1991). Senyawa-senyawa tersebut masing-masing diubah menjadi flavin mononukleotida dan asam lemak disertai dengan pelepasan emisi cahaya dengan panjang gelombang sekitar 
Tabel 4. Kelimpahan bakteri V. harveyi dalam tubuh larva udang galah yang mengalami kematian

Table 4. Vibrio harveyi abundance in the died larvae

\begin{tabular}{lc}
\hline \multicolumn{1}{c}{$\begin{array}{c}\text { Perlakuan } \\
\text { Treatments }\end{array}$} & $\begin{array}{c}\text { Vibrio harveyi } \\
\text { (cfu/larva) }\end{array}$ \\
\hline Strain Ogan (Ogan strain) & $3.5 \times 10^{2}$ \\
Strain Barito (Barito strain) & $7.4 \times 10^{2}$ \\
Strain Asahan (Asahan strain) & $8.5 \times 10^{3}$ \\
Strain Ciasem (Ciasem strain) & $5.5 \times 10^{3}$ \\
Strain GIMacro (GIMacro strain) & $8.9 \times 10^{2}$ \\
Kontrol (Control) & TT \\
\hline
\end{tabular}

Keterangan (Note): TT = Tidak terdeteksi $($ Undetected $)$

$490 \mathrm{~nm}$. Gen-gen yang mengkodekan fungsi perpendaran ini disandikan dalam suatu operon yang disebut dengan operon lux (Meighen, 1991). Hasil identifikasi tersebut menunjukkan bakteri yang menginfeksi larva adalah bakteri $V$. harveyi (Lampiran 1).

\section{Kualitas Air}

Pengukuran parameter kualitas air dilakukan pada awal dan akhir perlakuan. Pengukuran ini dilakukan untuk monitoring kualitas air selama penelitian berjalan dan juga untuk memastikan bahwa larva udang galah tidak mengalami kematian akibat lingkungan yang buruk. Pada Tabel 5 disajikan nilai kualitas air yang meliputi: suhu, kandungan oksigen terlarut (dissolve oxygen/DO), salinitas, $\mathrm{pH}$, amonia $\left(\mathrm{NH}_{3}\right)$, dan nitrit $\left(\mathrm{NO}_{2}{ }^{-}\right)$selama masa perlakuan.

Air media pemeliharaan merupakan ruang lingkup tempat hidup, tumbuh, dan berkembang larva udang galah sehingga kualitasnya harus baik. Pada Tabel 5 disajikan nilai parameter kualitas air selama masa pemeliharaan. Nilai parameter suhu selama masa pemeliharaan pada semua perlakuan berkisar antara $28^{\circ} \mathrm{C}-29^{\circ} \mathrm{C}$ di mana nilai ini merupakan nilai yang optimum bagi kehidupan larva udang galah. Menurut D'Abramo et al. (1995); Spotts (2001), udang galah hidup optimal pada suhu air berkisar $26^{\circ} \mathrm{C}-30^{\circ} \mathrm{C}$.

Oksigen terlarut memegang peranan penting bagi kehidupan organisme perairan. Kisaran kandungan oksigen terlarut selama masa pemeliharaan pada semua perlakuan berkisar antara 4,96-5,13 mg/L. Menurut New
(2002), kandungan oksigen terlarut yang optimal untuk udang galah berkisar $3-7 \mathrm{mg} / \mathrm{L}$, dan menimbulkan stres jika di bawah $2 \mathrm{mg} / \mathrm{L}$. Spotts (2001) mengemukakan bahwa kandungan oksigen yang tinggi memegang peranan penting bagi sintasan dan pertumbuhan udang galah. Udang galah mempunyai toleransi terhadap oksigen rendah untuk periode waktu singkat, meskipun pada kondisi tersebut udang galah menunjukkan penurunan nafsu makan.

Nilai pH (derajat keasaman) menentukan layak tidaknya suatu lingkungan perairan bagi udang, karena $\mathrm{pH}$ mempengaruhi laju reaksi kimia serta tekanan osmosis yang terjadi di perairan dan tubuh udang (Wardoyo, 1998 dalam Guntur, 2006). Nilai pH selama masa pemeliharaan di semua perlakuan berada pada kisaran 7-8,1. Nilai tersebut berada pada kisaran nilai $\mathrm{pH}$ air yang baik untuk pemeliharaan larva udang galah. Hal tersebut dengan pendapat New (2002), bahwa pH optimum bagi larva udang galah berkisar 7,0-8,5.

Kisaran salinitas media pemeliharaan larva udang galah selama masa pemeliharaan di semua perlakuan berada pada kisaran 10-11 ppt. Nilai salinitas ini berada pada kisaran optimal untuk pemeliharaan larva udang galah. Sesuai dengan pendapat Praseno et al. (2001), pada fase larva udang galah mampu tumbuh dengan baik pada salinitas 8-15 ppt. Nilai salinitas dan $\mathrm{pH}$ berkaitan dengan proses osmoregulasi yang terjadi antara tubuh udang dan lingkungannya. Pada nilai salinitas dan $\mathrm{pH}$ optimum udang tidak memerlukan energi yang lebih besar untuk melakukan proses 


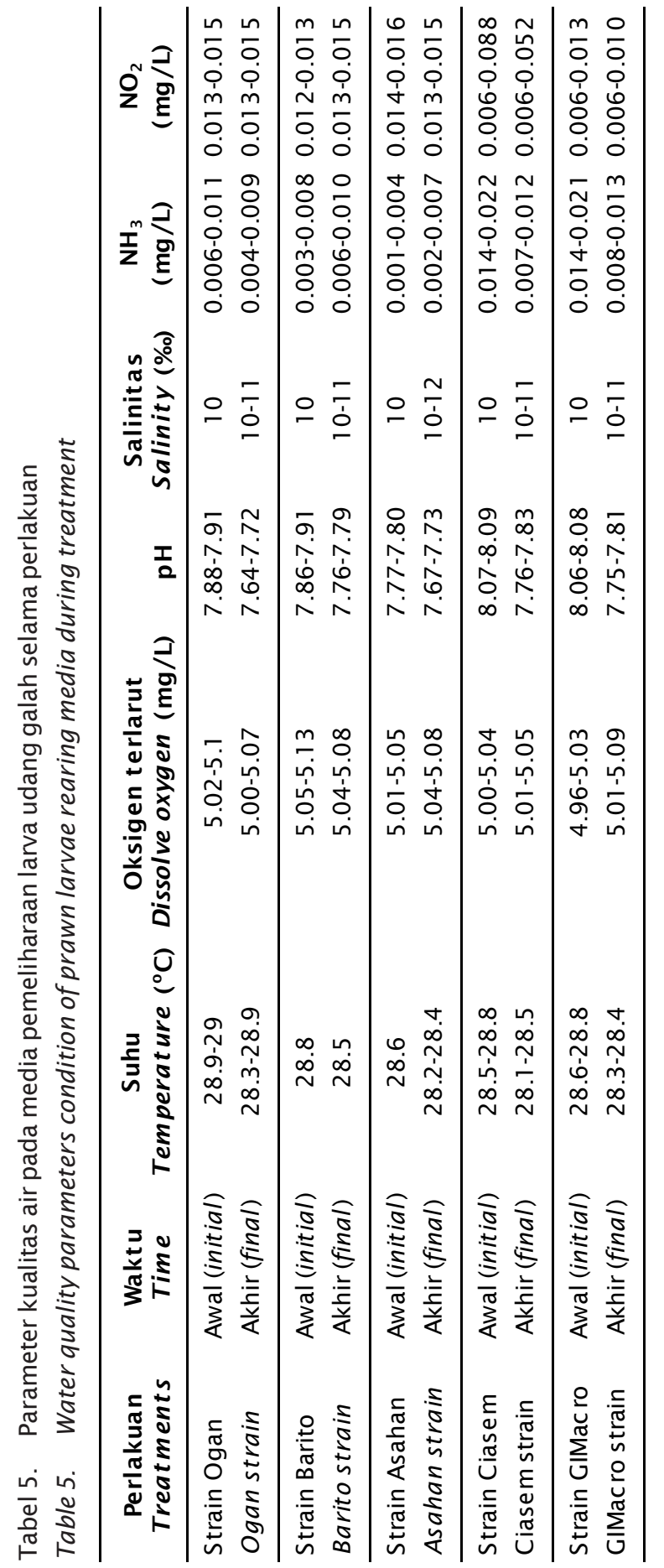


osmoregulasi dan energi dapat dialokasikan lebih besar untuk proses pertumbuhan (Praditia, 2009).

Nilai amonia $\left(\mathrm{NH}_{3}\right)$ selama masa pemeliharaan pada semua perlakuan berkisar antara 0,001-0,022 mg/L. Kondisi ini sangat aman untuk kehidupan dan pertumbuhan larva udang galah. Menurut New (2002), kandungan amonia yang optimal bagi budidaya udang galah adalah $<0,3 \mathrm{mg} / \mathrm{L}$. Sedangkan kisaran nitrit $\left(\mathrm{NO}_{2}{ }^{-}\right)$selama masa pemeliharaan di semua perlakuan berkisar antara 0,006-0,016 $\mathrm{mg} / \mathrm{L}$, dan masih sangat layak untuk kehidupan dan pertumbuhan larva udang galah. Konsentrasi nitrit yang ideal bagi pemeliharaan larva udang galah adalah $<0,1 \mathrm{mg} / \mathrm{L}$ (Mallasen $\&$ Valenti, 2006). Amonia dan nitrit merupakan buangan nitrogen yang bersifat merugikan bagi budidaya. Keduanya berpengaruh negatif pada udang dalam hal kemampuan transpor oksigen (Boyd, 1991).

Kisaran-kisaran nilai kualitas air yang diperoleh pada media pemeliharaan larva selama penelitian berlangsung berada pada kisaran optimal bagi larva udang galah, sehingga secara umum tidak berpengaruh terhadap kematian larva udang galah. Jadi, kematian larva udang galah selama penelitian berlangsung disebabkan oleh perlakuan yang diberikan, yaitu inokulasi bakteri patogen $V$. harveyi.

\section{KESIMPULAN}

Hasil yang diperoleh melalui penelitian yang telah dilakukan dapat disimpulkan bahwa larva udang galah strain Barito, Kalimantan Selatan memiliki sifat unggul dari segi ketahanan terhadap bakteri Vibrio harveyi, karena dengan perendaman pada media dengan konsentrasi $V$. harveyi $10^{5} \mathrm{cfu} / \mathrm{mL}$ selama 48 jam sintasan larva cukup tinggi, yaitu $75 \%$. Hasil ini memberikan informasi bahwa alternatif lain untuk mengendalikan penyakit vibriosis pada pembenihan udang galah adalah dengan menggunakan induk udang galah strain Barito Kalimantan Selatan, baik sebagai galur murni atau komponen hibridisasi untuk menghasilkan strain udang galah dengan pertumbuhan cepat dan daya tahan tinggi terhadap infeksi bakteri patogen.

\section{DAFTAR ACUAN}

APHA. 2005. Standard methods for the examination of water \& wastewater. $21^{\text {st }}$ edition.
APHA AWWA WEF, Washington, xxxvii + $1207 \mathrm{pp}$.

Aquacop. 1983. Intensive larval rearing in clear water of Macrobrachium rosenbergii (de Man, Avenue stock), at The Centre Oceanologique du Pacifique, Tahiti. CRC Handbook of Mariculture, I: 179-187.

Bibiana, W.L. 1994. Analisis mikroba di laboratorium. PT Raja Grafindo Persada, Jakarta, $\mathrm{vii}+168 \mathrm{hlm}$.

Boyd, C.E. 1991. Water quality management and aeration in shrimp farming. Terjemahan Sukadi. Pedoman Teknis dari Proyek Penelitian dan Pengembangan Perikanan. Pusat Penelitian Pengembangan Perikanan, Jakarta, $19 \mathrm{hlm}$.

Clesceri, L.S., Greenberg, A.E., \& Trussells, R.R. 1989. Standard methods for the examination of water and waste water. $17^{\text {th }}$ ed. Port City Press, Baltimore, xxxv + 1192 pp.

Collins, C.H., Lyne, P.M., \& Grange, J.M. 1995. Microbial methods. Butterworth-Heinemann Ltd, Oxford, ix + 493 pp.

D’Abramo, L.R., Daniels, W.H., Fondren, M.W., \& Brunson, M.W. 1995. Management Practices for culture of freshwater prawn (Macrobrachium rosenbergii) intemperate climates. MAFES Bulletin, 1030: 12 pp.

Goddard, S. 1996. Feed management in intensive aquaculture. Chapman and Hall, New York, $194 \mathrm{pp}$.

Guntur. 2006. Pengaruh pemberian bakteri probiotik Vibrio skt-b melalui Artemia terhadap pertumbuhan dan kelangsungan hidup larva udang windu (Penaeus monodon Fab.). Skripsi. Institut Pertanian Bogor, $38 \mathrm{hlm}$.

Hadie, L.E. \& Hadie, W. 2002. Budidaya Udang Galah GIMacro. Penebar Swadaya, Jakarta, $48 \mathrm{hlm}$.

Hadioetomo, R.S. 1993. Mikrobiologi Dasar dalam Praktek: Teknik dan Prosedur Dasar Laboratorium. Gramedia Pusaka Utama, Jakarta, $52 \mathrm{hlm}$.

Hoa, T.T., Hoang, D.T., \& Phuong, N.T. 2006. Study on disease in giant freshwater prawns (Macrobrachium rosenbergii): A Review. Departement of Fisheries Biology, College of Aquaculture and Fisheries, Can Tho University, p. 1-7.

Holt, J.G., Krieg, N.R., Sneath, P.H.A., Staley, J.T., \& Williams., S.T 1994. Bergey's Manual of Determinative Bacteriology. Ninth Edition. Williams \& Wilkins. Baltimore, 787 pp. 
Huervana, F.H., de la Cruz, J.J.Y., \& Caipang, C.M.A. 2006. Inhibition of luminous Vibrio harveyi by "green water" obtained from tank culture of tilapia, Oreochromis mossambicus. Acta Ichthyol. Piscat., 36(1): 17-23.

Mallasen, M. \& Valenti, W.C. 2006. Effect of nitrite on larval development of giant river prawn Macrobrachium rosenbergii. Aquaculture, 261: 1,292-1,298.

Meighen, E.A. 1991. Molecular biology of bacterial bioluminescence. Microbial Rev., 55: 123-142.

New, M.B. 2002. Farming freshwater prawns a manual for the culture of the giant river prawn Macrobrachium rosenbergii. FAO Fisheries, United Kingdom, 468 pp.

Praditia, F.P. 2009. Pengaruh pemberian bakteri probiotik melalui pakan terhadap pertumbuhan dan kelangsungan hidup udang windu Penaeus monodon. Skripsi. Departemen Budidaya Perairan, Fakultas Perikanan dan IImu Kelautan, Institut Pertanian Bogor, $56 \mathrm{hlm}$.

Praseno, O., Hadie, W., \& Hadie, L.E. 2001. Distribusi geografis dan karakteristik ekologi udang galah. Prosiding Workshop Hasil Penelitian Udang Galah, 26 Juli 2001, Jakarta, $8 \mathrm{hlm}$.

Reed, L.J. \& Muench, H. 1938. A Simple method of estimating fifty percent endpoint. The American J. of Hygiene, 27: 493-497.

Sharshar, K.M. \& Azab, E.A. 2008. Studies on diseased freshwater prawn Macrobrachium rosenbergii infected with Vibrio vulnificus. Pakistan J. of Biological Sciences, 11 (17): 2,092-2,100.
Spotts, D. 2001. Introducing Macrobrachium rosenbergii. Freshwater and Marine Aquarium, 4(7): 32-34 \& 74-75. http:// www.miami-aquaculture.com. [20 Juni 2009].

Steel, R.G.D. \& Torrie J.H. 1982. Principles and Procedur of Statistics a Biometrical Approach $2^{\text {nd }}$ ed. McGraw-Hill International Book Company, Japan, 208 pp.

Sukadi, M.F., Haryadi, J., Setiawan, \& Harry, I. 2006. Pembenihan udang skala rumah tangga di kawasan pesisir Kabupaten Lampung Selatan: Studi Kasus di Kecamatan Rajabasa dan Kalianda. Aquacultura Indonesiana, 7(1): 1-9.

Supriyadi, H., Hadie, L.E., \& Hadie, W. 2001. Insidensi infeksi bakteria pada udang galah (Macrobrachium rosenbergii). Prosiding Workshop Hasil Penelitian Udang Galah, 26 Juli 2001, Jakarta, 12 hlm.

Taufik, I., Sutrisno, \& Santosa K. 2001. Pengaruh insektisida klorpirifos etil terhadap pertumbuhan serta jaringan hepatopankreas udang galah (Macrobrachium rosenbergii) di laboratorium. Prosiding Workshop Hasil Penelitian Udang Galah, 26 Juli 2001, Jakarta, $11 \mathrm{hlm}$.

Tonguthai, K. 1997. Diseases of the Freshwater Prawn, Macrobrachium rosenbergii. AAHRI Newsletter Article, 4(2): 15.

Widanarni. 2004. Penapisan bakteri probiotik untuk biokontrol vibriosis pada larva udang windu: konstruksi penanda molekuler dan esai pelekatan. Disertasi. Program Pascasarjana, Institut Pertanian Bogor, $268 \mathrm{hlm}$.

Zonneveld, N., Huisman, E.A., \& Boon, J.H. 1991. Prinsip-prinsip Budidaya Ikan. Gramedia Pustaka Utama. Jakarta, $318 \mathrm{hlm}$. 
Lampiran 1. Identifikasi bakteri dari larva yang terinfeksi (mati)

Appendix 1. Identification of bacteria from the died infected larvae

\begin{tabular}{|c|c|}
\hline $\begin{array}{l}\text { Parameter } \\
\text { Parameters }\end{array}$ & $\begin{array}{l}\text { Hasil uji } \\
\text { Result }\end{array}$ \\
\hline Gram & - \\
\hline Bentuk sel (Cell form) & Batang (basil) \\
\hline Oxidase & + \\
\hline Lysine Decarboxylase & - \\
\hline Acid from glucose & + \\
\hline ONPG & - \\
\hline Voges Proskauer & - \\
\hline Gelatin Liquefaction & - \\
\hline Acid from Sorbitol & - \\
\hline Acid from Lactose & - \\
\hline Ac id from Raffinose & - \\
\hline Motility & + \\
\hline Ornithine Decarboxyl & - \\
\hline Ac id from Mannitol & - \\
\hline Indole & - \\
\hline Citrate Utilization & - \\
\hline Malonate Inhibition & - \\
\hline Acid from Rahamnose & - \\
\hline Ac id from Arabinose & - \\
\hline Ac id from Salic in & - \\
\hline Nitrate Reduction & + \\
\hline $\mathrm{H}_{2} \mathrm{~S}$ Production & - \\
\hline Acid from Xylose & - \\
\hline Urea Hydrolysis & - \\
\hline Tryptophan Deaminase & - \\
\hline Acid from Inositol & - \\
\hline Acid from Sucrose & - \\
\hline Ac id from Adonitol & - \\
\hline Arginine Dihydrolase & + \\
\hline Hasil identifikasi (Identification result) & Vibrio harveyi \\
\hline
\end{tabular}

